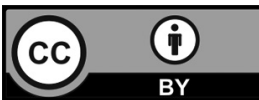

\title{
COMPARATIVE ANALYSIS OF LONG-EARED OWL (ASIO OTUS) WINTER DIET FROM TWO EUROPEAN CITIES - CHISINAU (REPUBLIC OF MOLDOVA) AND BACAU (ROMANIA)
}

\author{
Victoria NISTREANU ${ }^{1}$, Dalia PARASCHIV ${ }^{2}$, Alina LARION ${ }^{1}$ \\ ${ }^{1}$ Institute of Zoology, Chisinau, Republic of Moldova, \\ ${ }^{2}$ Museum Complex of Natural Sciences, Bacau, Romania
}

Corresponding author: Victoria Nistreanu, e-mail: vicnistreanu@gmail.com

Key words: Asio otus, urban environment, trophic spectrum, rodents, Microtus voles.

Cuvinte cheie: Asio otus, mediu urban, spectru trofic, rozătoare, speciile genului Microtus.
Introduction. Many rodent species are important pests for agriculture and for urban areas. The long-eared owl is a predator that exerts constant pressure on rodent density.

Material and methods. The studies were performed in winters of 2011-2013 in the cities of Chisinau and Bacau, where 599 and 82 pellets of Asio otus were collected, respectively. The prey items were identified from cranial bones extracted from pellets.

Results. Long-eared owl's diet in both sites consists of mammals and birds, with rodents being the dominant trophic component. The Microtus species were the main prey with the abundance $\geq 70 \%$ in both sites. In Chisinau a high proportion of Mus species was registered in the diet. The total biomass of prey constituted $43953 \mathrm{~g}$ in Chisinau and 7038 in Bacau. The highest biomass belongs to Microtus species, with $31710 \mathrm{~g}$ and $5220 \mathrm{~g}$, respectively. The trophic niche width in Chisinau constituted 0.089 and varied monthly from 0.058 to 0.28 . In Bacau the WTNs was of 0.134 and varied slightly among the study months.

Conclusions. The rodents were the main trophic source and constituted $\geq 96 \%$ in both sites. The prey diversity was higher in Chisinau, that was due to a larger city territory and to a higher number of wintering long-eared owls. The close values of trophic niche width in Chisinau and Bacau confirmed the high hunting specialization of the long-eared owl.

\section{ANALIZA COMPARATIVĂ A DIETEI DE IARNĂ A CIUFULUI DE PĂDURE (ASIO OTUS) ÎN DOUĂ ORAȘE EUROPENE - CHIȘINĂU (REPUBLICA MOLDOVA) ȘI BACĂU (ROMÂNIA)}

Introducere. Multe specii de rozătoare sunt dăunători ai agriculturii, inclusiv și zonele urbane. Ciuful de pădure este o specie de păsări de pradă care exercită o presiune relativ constantă asupra densității rozătoarelor.

Material și metode. Cercetările au fost efectuate în orașele Chișinău și Bacău, în perioada de iarnă a anilor 2011-2013, unde au fost colectate 599 și, respectiv, 82 de ingluvii. Au fost identificate speciile pradă după oasele craniene extrase din ingluvii.

Rezultate. Spectrul trofic al ciufului de pădure din ambele situri este format din mamifere și păsări, rozătoarele fiind componentul trofic principal. În ambele situri speciile genului Microtus au fost prada principală cu peste 70\%. Biomasa totală a prăzii a constituit 43953 g în Chișinău, iar în Bacău - 7038 g. Cea mai mare biomasă aparține speciilor gen. Microtus - $31710 \mathrm{~g}$ la Chișinău, $5220 \mathrm{~g}$ - la Bacău. Lătimea nișei trofice în Chișinău a fost de 0,089 și a variat lunar de la 0,058 la 0,28. La Bacău, WTNs a constituit 0,134 și a variat lunar în limite mici.

Concluzii. Rozătoarele au reprezentat sursa trofică principală - peste 96\% în ambele situri. In localitatea cu suprafața mai mare, spectrul trofic s-a dovedit a fi mai variat. Diversitatea speciilor pradă este mai mare în Chișinău și se datorează suprafeței mai mari a orașului și numărului mai mare de ciufi în colonie. Valorile apropiate ale lățimii nișei trofice în Chișinău și Bacău confirmă specializarea înaltă a ciufului de pădure. 


\section{INTRODUCTION}

Many of the rodent species are important pests of agricultural crops and cereal deposits, including urban areas. The nocturnal prey birds are regulatory species that contribute to maintaining rodent density at more or less constant level. The long-eared owl (Asio otus L.) is a sedentary bird and one of the most widespread in Europe (1-5). During the winter period the density of species increases on the account of the migrant individuals from the northern regions and they form colonies of several tens of individuals. In most cases, the owls prefer to winter each year in the same place. The hunting sectors of the long-eared owl are open type biotopes, where they mainly hunt rodents and occasionally birds, shrews and bats. Following the digestion process, the prey birds regurgitate the indigestible remnants of eaten a-nimals (bones, hair, feathers, fur) in the form of pellets. The pellets analysis can provide important data regarding the feeding regime of the bird, the fauna of small mammals in a certain area, their density and their seasonal and annual dynamics, etc. The long-eared owl is well adapted to anthropic environment and its wintering colonies are frequently registered in urban localities (4).

Taking into consideration the huge importance of long-eared owl trophic activity in biological control of rodent pest species, especially in winter period, its diet was rather well studied in many regions of Europe (1-10). In the Republic of Moldova and Romania the diet of long-eared owl was also rather well studied in different areas of the countries (11-18). There are several studies concerning the long-eared owl's diet in urban areas (19-26).

The long-eared owl is a feeding specialist predator and not all species are equally hunted prey. The attractiveness of a prey species depends on specific qualities, the most important of which is the size (1). The long-eared owl shows strong preference for Microtus voles across Europe, but in urban areas it hunts in open type biotopes outside the city and/or use alternative prey (27). In winter, A. otus is capable to localize the prey under a snow cover of 40-50 cm (14). As adaptations of winter diet to urban environment can be considered the use of higher ratio of synanthropic rodent species (Mus musculus, Rattus norvegicus), of bird species as well as more diverse trophic spectrum $(4,24,28-33)$.
The aim of the paper is to perform a comparative analysis of long-eared owl winter diet in two European cities, Chisinau and Bacau, with similar environmental - climatic conditions and rather different anthropic impact, in order to emphasize the similarities and the differences.

\section{MATERIAL AND METHODS}

The studies were performed in winter periods of 2011-2012 and 2012-2013 in Chisinau and Bacau cities. Chisinau is a large city with the surface of $123 \mathrm{~km}^{2}$, situated in the central part of the Republic of Moldova at the altitude of $82 \mathrm{~m}$, coordinates $47001^{\prime} \mathrm{N} 28052$ ' E. Bacau city is the major city of Bacau county, with the surface of $43.19 \mathrm{~km}^{2}$, situated in eastern part of Romania at the altitude of $165 \mathrm{~m}$, coordinates 46035' N 26055' E. The climate of both cities is humid continental with warm summers and cool, windy winters. The winter period lasts 78-80 days. The average temperature in winter is $-2.3^{\circ} \mathrm{C}$ in Chisinau and $-4 \mathrm{C}$ in Bacau city, while the minimum temperature in January and February can drop below $-20^{\circ} \mathrm{C}$.

In Chisinau city a colony of long-eared owl (Asio otus L.) of 38 individuals was located in a courtyard of a school from Ciocana district with several dozens of tall coniferous and deciduous trees (Picea abies, Populus alba, P. tremula, Salix alba) suitable for long-eared owl individuals. In Bacau city a small colony of 7 individuals was located in the yard of the Astronomical Observatory, with several trees of Thuja orientalis, Picea abies, Carpinus betulus. Both locations are situated within the cities limits in heavily urbanized areas.

In Chisinau 599 pellets have been collected and in Bacau 82 pellets. Each pellet was measured, weighed and afterwards unfolded. The bone fragments were cleaned and sorted into categories. Small mammal species were determined accor-ding to cranial bones and dentition $(34,35)$. The sibling species Microtus arvalis and M. rossiaemeridionalis, Mus musculus and M. spicilegus that can't be differentiated morphologically were considered as genus Microtus and Mus, respe-ctively.

The ecological analysis of the prey species was performed using the indexes of abundance ( $A=n 0^{*} 100 / N$, where no - number of individuals of a species, $\mathrm{N}$ - total number of individuals); frequency ( $\mathrm{F}=$ nop*100/N, where nop - number of pellets with certain species, $\mathrm{N}$ - number of pellets); total biomass of consumed prey $\left(B=\mathrm{no}^{*} \mathrm{G}\right.$, 
where no - number of individuals of a species, G mean weight of one individual). The mean weight of prey individual was calculated from our own data gathered during long term studies of small mammals and bats. The trophic niche width was estimated using the $B$ Levins' index: $\mathrm{B}=1 / \Sigma \mathrm{p}^{2},(36)$, in its standardized version Bs (37): $B s=(\mathrm{B}-1) /(\mathrm{n}$ $1)$, where $p$ is the fraction of items in the diet, and $\mathrm{n}$ is the number of possible food categories (38). Bs ranges from $0(100 \%$ utilization of a single food category) to 1 (equal use of all categories).

During the study none of animals was injured or sacrificed.

\section{RESULTS}

In Chisinau the length of analyzed pellets varied from 1.16 to $6.95 \mathrm{~cm}$ with the average of $3.32 \mathrm{~cm}$. The pellet weight varied between 1.2 and $6.07 \mathrm{~g}$ with the average of $2.52 \mathrm{~g}$. After cleaning the bones, 1489 individuals were identified. The number of individuals per pellet varied from 1 to 6 , the average constituted 2.46 individuals. In Bacau the pellet length varied between 1.2 and $5.6 \mathrm{~cm}$. The minimal number of individuals/pellets was 1 , the maximal number was 5 and the average was 2.56. After cleaning the bones 223 individuals were identified.

The trophic spectrum of long-eared owl in Chi-sinau consisted of mammals from 3 orders (Sorico- morpha, Rodentia, Chiroptera) and passe-rine birds (fig. 1). In Bacau rodents and passerine birds have been identified (fig. 2). In both sites Microtus species dominated with $70.99 \%$ in Chi-sinau and $76.31 \%$ in Bacau. The house mouse is the second species in Chisinau pellets (10.88\%), while in Bacau it constituted less than $1 \%$. The genus Apodemus were represented by 4 species in Chisinau and by 3 species in Bacau. In both sites the most numerous was $A$. sylvaticus with $10.34 \%$ and $10.97 \%$, respectively (fig. 1, fig. 2). Other Apodemus species constituted about $10 \%$ in Bacau pellets, while in Chisinau their ratio was less than $4 \%$. In Chisinau the diet of long-eared owl was more diverse, probably due to much larger number of individuals that hunted in a larger variety of ecosystems. Here were identified shrews and bats in lower ratio, while the birds constituted $2.55 \%$ and in Bacau - 2.19\%. Among rodents two more species have been registered - the arboreal rodent Muscardinus avellanarius and the synanthropic species Rattus norvegicus with very low ratio of $0.13 \%$.

The diversity indexes (Shannon and Simpson) are higher in Chisinau site 0.45 and 1.89 , respectively, than in Bacau 0.71 and 1.68. Although the species number is much higher in Chisinau, the difference between diversity indexes is not very high, due to more even distribution of the species in Bacau site.

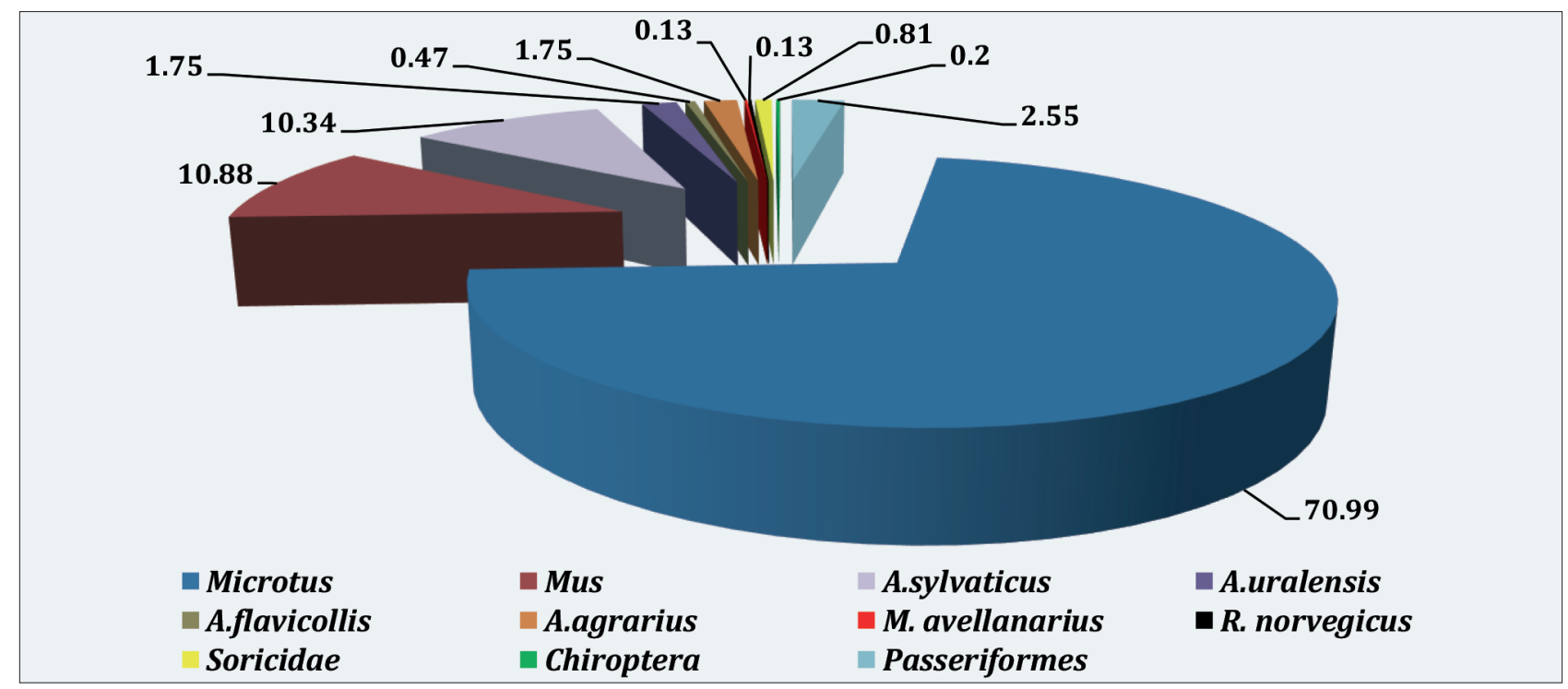

Figure 1. Trophic spectrum of long-eared owl in Chisinau city in 2011-2012.

The highest frequency in pellets from both urban areas belongs to Microtus species that was found in most of the pellets followed by Mus species and A. sylvaticus in Chisinau and by A. sylvaticus and $A$. flavicollis in Bacau (tab. 1). The birds, represented by Passeriformes had a frequency of $6.43 \%$ in Chisinau and $6.1 \%$ in Bacau. 
The total biomass of prey items constituted 43 $953 \mathrm{~g}$ in 6 study months in Chisinau and 7038 in 4 months in Bacau. The highest biomass belongs to Microtus species, with $31710 \mathrm{~g}$ in Chisinau and
5220 in Bacau (tab. 2). In both sites a decrease of prey number and biomass was registered from November to December and from November to February in Chisinau.

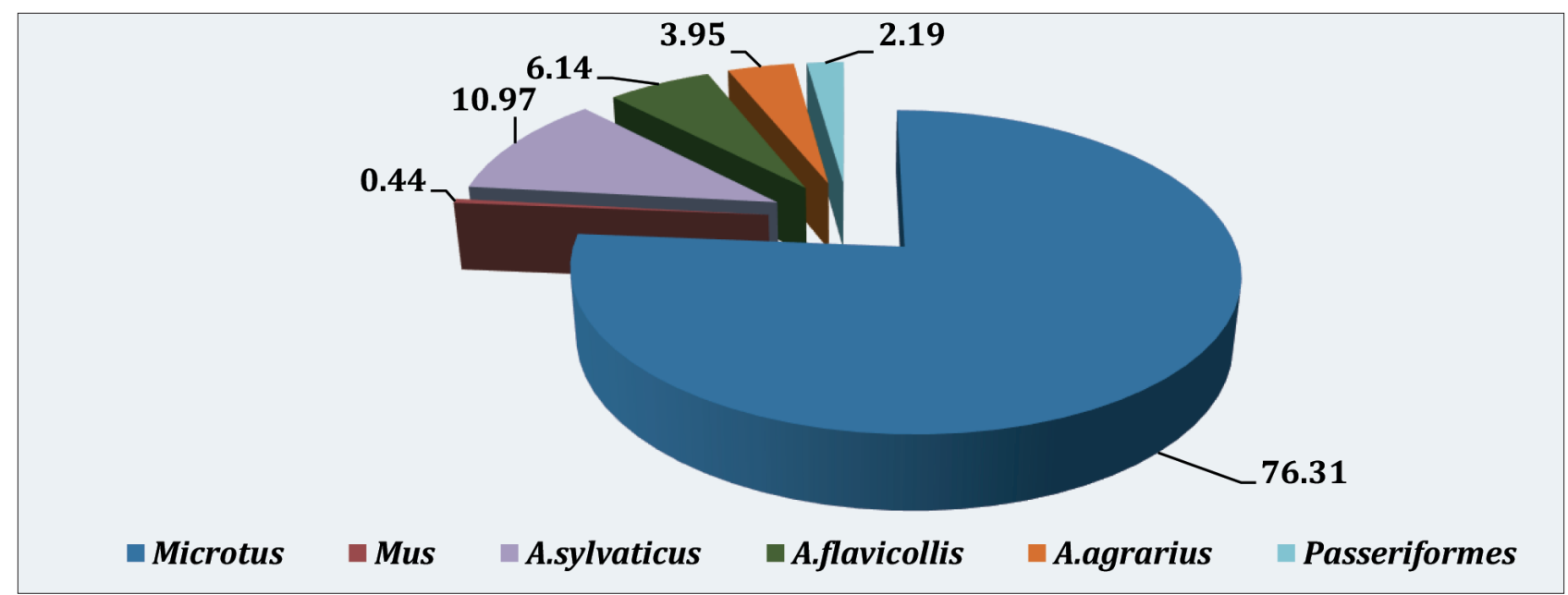

Figure 2. Trophic spectrum of long-eared owl in Bacau city in 2011-2012.

Table 1. Frequency of animal species in Asio otus pellets.

\begin{tabular}{|c|c|c|c|c|c|}
\hline \multirow{2}{*}{ Nr. } & \multirow{2}{*}{ Genus/species } & \multicolumn{2}{|c|}{ Chisinau } & \multicolumn{2}{|c|}{ Bacau } \\
\hline & & No pellets & Frequency, \% & No pellets & Frequency, $\%$ \\
\hline 1. & Microtus & 368 & 61.44 & 62 & 75.61 \\
\hline 2. & Mus & 136 & 22.71 & 1 & 1.22 \\
\hline 3. & A. sylvaticus & 125 & 20.87 & 21 & 25.61 \\
\hline 4. & A. uralensis & 25 & 4.17 & - & - \\
\hline 5. & A. flavicollis & 6 & 1.0 & 12 & 14.63 \\
\hline 6. & A. agrarius & 24 & 4.01 & 9 & 10.98 \\
\hline 7. & M. avellanarius & 2 & 0.33 & - & - \\
\hline 8. & R. norvegicus & 2 & 0.33 & - & - \\
\hline 9. & Soricomorpha & 10 & 1.67 & - & - \\
\hline 10. & Chiroptera & 2 & 0.33 & - & - \\
\hline 11. & Passeriformes & 38 & 6.34 & 5 & 6.1 \\
\hline
\end{tabular}

The trophic niche index in Chisinau site was 1.89 and varied monthly between 1.58 to 3.77 . The standardized index was of 0.089 and varied monthly from 0.058 to 0.28 and indicate that in December 2012 the prey used belonged to many categories with more even distribution. In Bacau the trophic niche index was 1.67 with low variation degree between months. The standardized index was of 0.134 and varied slightly among the studied months (tab. 2). In Bacau WTNs index was slightly higher because only prey categories hunted there were considered.

\section{DISCUSSIONS}

In both cities the Microtus voles are the most important prey item in the winter diet of Long-eared owl, as previously registered in open land ecosystems thorough Europe $(1,2,3,5,7,9,10,39,40$, $41,42)$, as well as in urban areas $(17,21,22,24$, $25,29,43,44)$. Apodemus species constitute an important trophic source for long-eared owl in urban area. Their share can vary between $3 \%$ and $66 \%$ $(17,23,28,39,40,44)$ depending on location, climatic conditions, hunting sectors and prey availability. In some urban areas the Apodemus species even were the most abundant prey during winter period $(28,29,43)$. 
The difference between the ratio of Mus species in both cities is very high. This fact can be explained by city size and structure. In Chisinau there are many tall buildings and a massive production of waste, while in Bacau small houses are most numerous and the city is much cleaner. The higher ratio of Mus species (up to 10\%) in winter diet of the long-eared owl was noted for large cities (9, $21,29,40,45)$ and much lower ratio, up to $3 \%$ in small cities $(17,24,43)$.

Among other rodent species in Chisinau pellets there were found $R$. norvegicus and $M$. avella- na-rius. The last one is arboreal species and usually hibernates during winter, therefore its share is very low in different regions of Europe, up to 1\% $(21,28)$, but in most of studies it wasn't re-gistered. The brown rat had a very low ratio in Chisinau pellets and wasn't registered in Bacau, although in previous studies it was found in A. otus diet with $0.14 \%$ (23). In many other studies in European cities the species also had a low share, up to $5 \%$ (9, $20,21,29,31,39)$, but in some large cities the species is one of the main preys, reaching about $20 \%$ and $60-70 \%$ biomass (28).

Table 2. Individual number and biomass of prey species in studied months.

\begin{tabular}{|c|c|c|c|c|c|c|c|c|c|c|c|c|c|}
\hline \multicolumn{2}{|l|}{ City } & \multicolumn{7}{|c|}{ Chisinau } & \multicolumn{5}{|c|}{ Bacau } \\
\hline Species & Par. & XI.11 & XII.11 & I.12 & II.12 & XI.12 & XII.12 & Total & XI.11 & XII.11 & XI.12 & XII.12 & Total \\
\hline \multirow{2}{*}{ Microtus } & No & 346 & 242 & 175 & 174 & 67 & 53 & 1057 & 53 & 27 & 63 & 31 & 174 \\
\hline & BM & 10380 & 7260 & 5250 & 5220 & 2010 & 1590 & 31710 & 1590 & 810 & 1890 & 930 & 5220 \\
\hline \multirow{2}{*}{ Mus } & No & 64 & 29 & 16 & 19 & 21 & 13 & 162 & - & - & 1 & - & 1 \\
\hline & BM & 1152 & 522 & 288 & 342 & 378 & 234 & 2916 & - & - & 18 & - & 18 \\
\hline \multirow{2}{*}{ A. sylvaticus } & No & 37 & 23 & 19 & 31 & 30 & 14 & 154 & 9 & 4 & 9 & 3 & 25 \\
\hline & BM & 1036 & 644 & 532 & 868 & 840 & 392 & 4312 & 252 & 112 & 252 & 84 & 700 \\
\hline \multirow{2}{*}{ A. uralensis } & No & 5 & 7 & 4 & 7 & 3 & - & 26 & - & - & - & - & 0 \\
\hline & BM & 115 & 161 & 92 & 161 & 69 & - & 598 & - & - & - & - & 0 \\
\hline \multirow{2}{*}{ A. flavicollis } & No & 2 & - & 1 & 2 & - & 2 & 7 & 5 & - & 6 & 3 & 14 \\
\hline & BM & 70 & - & 35 & 70 & - & 70 & 245 & 175 & - & 210 & 105 & 490 \\
\hline \multirow{2}{*}{ A. agrarius } & No & 8 & 7 & 2 & 4 & 3 & 2 & 26 & 2 & 1 & 5 & 1 & 9 \\
\hline & BM & 200 & 175 & 50 & 100 & 75 & 50 & 650 & 50 & 25 & 125 & 25 & 225 \\
\hline \multirow{2}{*}{ R. norvegicus } & No & - & - & - & - & 2 & - & 2 & - & - & - & - & 0 \\
\hline & BM & - & - & - & - & 300 & - & 300 & - & - & - & - & 0 \\
\hline \multirow{2}{*}{ M. avellanarius } & No & - & 2 & - & - & - & - & 2 & - & - & - & - & 0 \\
\hline & BM & - & 40 & - & - & - & - & 40 & - & - & - & - & 0 \\
\hline \multirow{2}{*}{ Soricidae } & No & - & - & 4 & 1 & 5 & 2 & 12 & - & - & - & - & 0 \\
\hline & BM & - & - & 32 & 8 & 40 & 16 & 96 & - & - & - & - & 0 \\
\hline \multirow{2}{*}{ Chiroptera } & No & - & - & - & - & 3 & - & 3 & - & - & - & - & 0 \\
\hline & BM & - & - & - & - & 36 & - & 36 & - & - & - & - & 0 \\
\hline \multirow{2}{*}{ Passeriformes } & No & 1 & 2 & 2 & 5 & 20 & 8 & 38 & - & 3 & - & 2 & 5 \\
\hline & BM & 75 & 150 & 150 & 375 & 1500 & 600 & 2850 & - & 225 & - & 150 & 375 \\
\hline Total ind. & No & 463 & 312 & 223 & 243 & 154 & 94 & 1489 & 69 & 35 & 84 & 40 & 228 \\
\hline Total biomass & BM & 13028 & 8852 & 6429 & 7144 & 5248 & 2952 & 43653 & 2067 & 1172 & 2495 & 1294 & 7028 \\
\hline WTN & & 1.71 & 1.62 & 1.58 & 1.95 & 3.77 & 2.7 & 1.89 & 1.64 & 1.61 & 1.72 & 1.63 & 1.67 \\
\hline WTNs & & 0.071 & 0.062 & 0.058 & 0.095 & 0.28 & 0.17 & 0.089 & 0.128 & 0.122 & 0.144 & 0.126 & 0.134 \\
\hline
\end{tabular}

Note: No - number of individuals, BM - biomass, WTN - width of trophic niche, WTNs - width of trophic niche standardized

Among other mammal groups in the diet of long-eared owl from Chisinau representatives of shrews and bats have been registered in very low percent. The shrews were represented by 4 species (Crocidura suaveolens, C. leucodon, Sorex minutus, S. araneus) and the bats - by 2 species (Eptesicus serotinus and Vespertilio murinus). The shrews are an alternative prey type for $A$. otus and are mostly hunted when the abundance of Microtus species is low. Furthermore, it was esta-blished that the sha- re of shrews in the owl's diet depends on the abundance of Microtus species and doesn't depend on shrew abundance in certain area (46). The presence of bats in the diet of $A$. otus is usually accidental and constitutes less than $0.5 \%$, while in the diet of other owl species (Tyto alba, Bubo bubo) Chiroptera groups can reach more than $10 \%(47,48)$.

The passerine birds constituted about $2-3 \%$ in $A$. otus diet from both cities, as well as in other urban studies, where their share constituted $0.5-10 \%$ 
$(26,29,39,40,43,49)$. The higher ratio of birds in some studies is conditioned by the abundant snow cover, when owls can shift their hunting areas into urban habitats, where the availability and density of bird populations, especially house sparrow, are higher (4). In the studied period in urban localities Chisinau and Bacau the snow cover did not exceed $10-20 \mathrm{~cm}$ and in November-December periods there was no snow cover, therefore the share of birds was rather low.

The prey diversity is higher in Chisinau site than in Bacau, which is due to larger surface of Chi-sinau city and to larger number of long-eared owl individuals. The higher diversity in larger cities was mentioned in many other studied $(21,28$,
29,40 ), while in smaller localities the diversity is lower $(22,26,39)$.

The long-eared owl is a specialized predator and hunt individuals that weight between $15 \mathrm{~g}$ and 50 $\mathrm{g}$, therefore, the ratio of preferred prey - Microtus voles remain high in spite of the availability of other prey types $(1,2)$. According to optimal foraging theory only the abundance of preferred prey influence upon the optimal choice of prey type, while the abundance of other prey types is not important (50). The close values of trophic niche breadth in Chisinau and Bacau prove the high hunting specialization of the long-eared owl and highlight its importance in rodent regulation in urban areas and surroundings.

\section{CONCLUSIONS}

1. The trophic spectrum of long-eared owl in Chisinau and Bacau cities consists of mammals and birds, the rodents being the dominant trophic source ( 8 species in Chisinau and 5 species in Bacau with over 95\%). The Microtus species were the main prey and constitute more than $70 \%$ in both sites.

2. The higher prey diversity in Chisinau in comparison to Bacau is due to larger surface of Chisinau city and to larger number of long-eared owl wintering individuals. In larger cities the trophic spectrum is more diverse.

3. The total biomass of prey items constituted $43953 \mathrm{~g}$ in 6 study months in Chisinau and 7038 in 4 months in Bacau. The highest biomass belongs to Microtus species, with $31710 \mathrm{~g}$ in Chisinau and 5220 in Bacau.

4. The trophic niche index in Chisinau site was 1.89 and varied monthly between 1.58 to 3.77. The standardized index was of 0.089 and varied monthly from 0.058 to 0.28 In Bacau the trophic niche index was 1.67 with low variation degree between months. The standardized index was of 0.134 and varied slightly among the studied months. The close values of trophic niche breadth in Chisinau and Bacau prove the high hunting specialization of the long-eared owl and highlight its importance in rodent regulation in urban areas and surroundings.

\section{CONFLICT OF INTERESTS}

The authors do not declare any conflict of interest.

\section{ACKNOWLEDGMENT}

The studies were performed within the fundamental project $15.187 .02 .11 \mathrm{~F}$ and applicative project 20.80009.7007.02.

\section{REFERENCES}

1. Birrer S. Synthesis of 312 studies on the diet of the Long-eared Owl Asio otus. Proc. Fourth World Owl Conf. Oct-Nov 2007, Groningen, The Netherlands. Ardea. 2009; 97(4):615-624.

2. Goszczyński J. Connection between predatory birds and mammals and their prey. Acta Theriol.1977; 22:399-430.
3. Romanowski J, Żmihorski M. Effect of season, weather and habitat on diet variation of a feedingspecialist: a case study of the long-eared owl, Asio otus in Central Poland. Folia Zool. 2008; 57(4): 411-419.

4. Wijnandts $\mathrm{H}$. Ecological energetics of the long-eared owl (Asio otus). Ardea. 1984; 72:1-92.

5. Korpimäki E. Diet composition, prey choice, and breeding success of Long-eared Owls: effects of multiannual fluctuations in food abundance. Can. J. Zool. 1992; 70:2373-2381.

6. Nilsson I. Seasonal changes in food of the long-eared owl in southern Sweden. Ornis Scand. 1981; 12:216-223.

7. Tome D. Diet composition of the long-eared owl in central Slovenia: seasonal variation in prey use. J. Raptor Res. 1994; 28:253-258. 
8. Galeotti P., Canova L. Winter diet or long-eared owls (Asio otus) in the Po Plain (Northern Italy). Raptor Res. 1994; 28(4):265-268.

9. Escala C., Alonso D., Mazuelas D, Mendiburu A., Vilches A., Arizaga J. Winter diet of Long-eared Owls Asio otus in the Ebro valley (NE Iberia). Revista Catalana d'Ornitologia. 2009; 25:49-53.

10.Sergio F, Marchesi L., Pedrini P. Density, diet and productivity of Long-eared Owls Asio otus in the Italian Alps: the importance of Microtus voles: Capsule Relatively large populations, feeding predominantly upon voles, were present at higher e-levations. Bird Study. 2008; 55(3):321-328.

11.Schnapp B. The fauna of micromammals from Valu-lui-Traian (Dobroudja) in the years 1958-1962, according to Asio otus (L.) pellets. Trav. Mus. Nat. His. Nat. Gr. Antipa. 1968; 8 (2):1045-1063.

12.Аверин ЮВ., Ганя ИМ. Хищные птицы Молдавии и их роль в природе и сельском хозяйстве. Издво «Картя Молдовеняскэ», 1966, 104 стр.

13.Анисимов ЕП. Факторы, определяющие добычу ушастой совы зимой. Вопросы экологии $u$ практического значения птиц и млекопитающих Молдавии. 1969; 3: с. 36-40.

14. Зубков НИ. Трофические связи сов в биоценозах Молдавии. Экология птиц и млекопита-ющих Молдавии. Кишинэу «Штиинца», 1981. с. 79-94.

15.Зубков НИ. Трофические связи и роль ушастой совы в биоценозах антропогенного ландшафта. Млекопитающие и птицы антропогенного ландшафта Молдавии и их практическое значение. Кишинэу «Штиинца», 1986. с. 41-59.

16. Petrescu A. Restes de prois de la nourriture d'Asio otus L. (Aves: Strigiformes) pendant l'ete dans la reserve naturelle Agigea (Roumanie). Trav. Mus. Nat. His. Nat. Gr. Antipa. 1997; 37:305-317.

17. Benedek A M., Sîrbu I. Dynamics of Asio otus L., 1758 (Aves: Strigiformes) winter-spring trophic regime in Western Plain (Romania). Trav. Mus. Nat. His. Nat. Gr. Antipa. 2010; 53:479 - 487.

18. Nistreanu V, Larion A, Postolachi V. Date preliminare privind dieta unor păsări răpitoare nocturne (Aves: Strigidae) în zona de nord a Republicii Mo-ldova. Agricultura durabilă în Republica Moldova: provocări actuale și perspective: Culegere de articole știintițifice, Filiala Bălți a Acad. de Științe a Moldovei. Bălți: Indigou Color, 2017. p. 356-360.

19. Barbu P, Barbu I. Colonii de ciufi (Asio otus otus L.) în câteva păduri din apropierea Bucureștiului. Necesitatea ocrotirii lor. Ocrotirea Naturii. 1972; 16(2):197-205.

20. Barbu P, Korodi Gal I. Despre hrana de iarnă a ciufului de pădure (Asio otus otus L.) din padurea Calcer — Cluj. Stud. Cercet. Biol., Ser. Zool. 1972; 24:497-504.
21. Murariu D., Andreescu I., Nesterov V. Les comprosants de la nourriture d'hiver d'Asio otus otus (L., 1758) du nord-est de Bucarest (Roumanie). Trav. Mus. Nat. His. Nat. Gr. Antipa. 1991; 31:415-420.

22. Laiu L, Murariu D. The food of the long-eared owl (Asio otus otus L.) (Aves: Stringiformes) in wintering conditions of the urban environment in Romania. Trav. Mus. Nat. His. Nat. Gr. Antipa. 1998; 40: 413-430.

23. Laiu L, Pasol P, Feneru F, Murariu D. The analysis of the winter food structure in Asio otus otus L. (Aves: Strigiformes) from Bacau and Iasi towns - Moldova (Romania). Trav. Mus. Nat. His. Nat. Gr. Antipa. 2002; 44: 423-430.

24. Banaru V, Coroiu I. Preliminary data on the micromammal fauna in the Someșul Mic basin (România) according to Asio otus otus L. pellets. Studia Univ. "Babeș-Bolyai", Cluj-Napoca, Biol. 1997; XLII (12):103-108.

25. Sike T. Hrana de iarnã a ciufului de pãdure (Asio otus) în Satu Mare - analize calitative si cantitative. Studii si Comunicãri. Seria Stiintele Naturale. 20032004; 4-5:222-231.

26. Nistreanu V, Larion A, Postolachi V. Small mammal diversity in steppe zone Sadaclia, Republic of Moldova. DROBETA, Științele Naturii. 2015; XXV:135-141.

27. Riegert J, Lövy M, Fainová D. Diet composition of Common Kestrels Falco tinnunculus and Long-eared Owls Asio otus coexisting in an urban environment. Ornis Fenn. 2009; 86:123-130.

28. Pirovano A, Rubolini D, Brambilla S, Ferrari N. Winter diet of urban roosting Long-eared Owls Asiootus in northern Italy: the importance of the Brown Rat Rattus norvegicus, Bird Study, 2000; 47:2:242-244.

29. Sharikov AV, Kholopova AV, Volkov SV, Makarova TV. The review of owls' diet in Moscow City and Moscow Region. In: Волков С.В., Шариков А.В., Морозов B.B. (ред.) Совы Северной Евразии: экология, пространственное и биотопическое распределение. М.; 2009. с. 188-203.

30. Sandor A, Kiss B. The diet of wintering Long-eared Owls (Asio otus) in Tulcea, Romania. Scientific Annals of the Danube Delta Institute. 2004; 10:49-54.

31.Sandor A, Kiss B. Birds in the diet of wintering long-eared owls (Asio otus) in the Danube Delta, Romania. J. Raptor Res. 2008, 42(4):292-295.

32. Kiat GY, G. Perlman, A. Balaban, Y. Leshem, I. Izhaki, M. Charter. Feeding specialization of urban Long-eared Owls Asio otus (Linnaeus, 1758), in Jerusalem, Israel. Zoology in the Middle East. 2008; 43:49-54.

33. Mori E, Bertolino S. Feeding ecology of Long-eared Owls in winter: an urban perspective. Bird Study. 2015; 62:2:257-261.

34.Popescu A, Murariu D. Fauna României. Mammalia, Rodentia. Editura Academiei Române, Vol. XVI (2), 2001, 210 pp. 
35. Pucek Z. (red.) Keys to vertebrate of Poland. Mammals. PWN - Polish Scientific Publishers, Warszava, 1981, 370 pp.

36. Levins R. Evolution in Changing Environments: Some Theoretical Explorations. Princeton: Princeton University Press; 1968. $121 \mathrm{pp}$.

37. Hurlbert SH. The Measurement of Niche Overlap and Some Relatives. Ecology, 1978; 59(1): 67-77.

38. Krebs CJ. Niche measures and resource preferences. Ecological Methodology, New York: Addison-Welsey Publishers. 1999. p. 455-496.

39. Romanowski J. Trophic ecology of Asio otus (L.) and Athene noctua (Scop.) in the suburbs of Warsaw. Pol. Ecol. Stud. 1988; 14: 223-234.

40. Bencová V, Kašpar T, Bryja J. Seasonal and interannual changes in diet composition of the Long-eared Owl (Asio otus) in Southern Moravia. Tichodroma. 2006; 18: 65-71.

41. Drebet MV. Diet of Long-eared Owl in the Kamenetskoe Prydenstrovie, Ukraine. In: Волков С.В., Шариков А.В., Морозов В.В. (ред.) Совы Северной Евразии: экология, пространственное и биотопическое распределение. М.; 2009, с. 55-58.

42. Petrovici M, Molnar P, Sandor A. Trophic niche overlap of two sympatric owl species (Asio otus Linnaeus, 1758 and Tyto alba Scopoli, 1769) in the North-Western part of Romania. North-Western Journal of Zoology. 2013; 9(2): 250-256.

Date of receipt of the manuscript: $27 / 01 / 2020$

Date of acceptance for publication: 17/02/2020

Victoria NISTREANU, ORCID: 0000-0002-9726-9684
43. Dzemian S, Pilacinska B, Pitucha G. Winter diet composition of urban long-eared owls (Asio otus) in Rzeszow (SE Poland). Biological let., 2012, vol. 49, isuue 2, p. 107-114.

44. Sharikov AV. Peculiarities of winter feeding in the long-eared owl (Asio otus) in settlements of Stavropol krai. Zool. Zh. 2006; 85:871-877.

45. Martelli C, Fastelli P. Svernamento e dieta del gufo commune Asio otus nella città di Grosseto. Gli Uccelli d'Italia. 2013; 38:85-91.

46. Korpimaki E, Norrdahl K. Avian and mammalian predators of shrews in Europe: regional diffe-rences, between year and seasonal variation and mortality due to predation. Ann. Zool. Fenn., 1989; 26(4):389-400.

47. Obuch J. The representation of bats (Chiroptera) in the diet of owls (Strigiformes) in Slovakia. Vespertilio. $1998 ; 3: 65-74$.

48.Шариков AB, Макарова ТВ. Рукокрылые в питании сов Северной Евразии. Plecotus et al. 2014; 17: 30-36.

49. Tulis F, Veselovský T, Birrer S. Different alternative diets within two subgroups in a winter roost of long-eared owls. Raptor Journal. 2019; 13. doi: 10.2478/srj20190002.

50. Pyke GH. Optimal foraging theory: a critical review. Annu. Rev. Ecol. Syst. 1984; 15:523-575. 